\title{
Ethnobotanical Investigation of Amaranth (Amaranthus spp) Cultivated in Burkina
}

\author{
Somtore Hamidou, Sawadogo Boureima*, Bationo-Kando Pauline, Kiebre Mariam, \\ Ouedraogo Jacques, Kiebre Zakaria
}

Training and Research Unit in Life and Earth Sciences, University Ouaga I Pr Joseph KI-ZERBO, Ouagadougou, Burkina Faso

\author{
Email address: \\ boureimasawadogo19@yahoo.fr (S. Boureima) \\ ${ }^{*}$ Corresponding author
}

\section{To cite this article:}

Somtore Hamidou, Sawadogo Boureima, Bationo-Kando Pauline, Kiebre Mariam, Ouedraogo Jacques, Kiebre Zakaria. Ethnobotanical Investigation of Amaranth (Amaranthus spp) Cultivated in Burkina. International Journal of Applied Agricultural Sciences.

Vol. 5, No. 2, 2019, pp. 50-55. doi: 10.11648/j.ijaas.20190502.14

Received: March 12, 2019; Accepted: April 16, 2019; Published: May 27, 2019

\begin{abstract}
This survey aims a better knowledge of the extent of the culture and the farmer fashion of management of the species of Amaranthus spp cultivated in Burkina in order to propose adequate methods of management, improvement and valorization. For that, a prospecting collects coupled of an ethnobotanical investigation have been achieved in the three climatical zones of the country. The prospecting collects permitted to constitute a collection of ninety-nine (99) accessions. The ethnobotanical investigation has showed that the culture of the amaranth is in net progression and is practiced in all climatical zones of the country. The producers who are mostly men $(64.45 \%)$ use the agromorphologic and organoleptic characteristic in the designation of the cultivars. Eight (08) morphotypes has been identified among witch green morphotype is the most cultivated. More than $60.43 \%$ of the producers get the seed by selection according to the needs of the consumers against only $23.02 \%$ by gift and $16.4 \%$ by purchase to variable prices from CFA $50(0.076 €)$ to 3500 (5.34 $€$ ) for a conditioning from 0.5 to $1 \mathrm{~kg}$. Furthermore seeds are often preserved in mixture with the ash, in bottles, in cans, in canaries or in sachets.
\end{abstract}

Keywords: Amaranths, Ethno Botanical Characterization, Diversity, Burkina

\section{Introduction}

Leafy-vegetables are very important in the food regime in the world, especially in Africa, Asia and Oceania, where they assure the essential part of the nutrimental and medicinal needs [1]. The Amaranthus kind includes about 800 species grouped together in two big groups that are the amaranths leaves and the amaranths seeds [2]. Some of these species like A. cruenthus, A. hypochondriacus, A. hybridus, etc. are edible and constitute an excellent food complement. The quality of its proteins is above the one of cow milk and soy. The leaves are rich in proteins, in vitamin $\mathrm{C}$, in beta-carotene, in calcium and iron [3-4]. Thereby, the amaranth reduces the illnesses linked to the deficiencies of calcium because it contains twice more than milk. It has some antioxidant properties and is easily digestible because its high content of fibers. It is richer in proteins (14 to $16 \%$ ) than the cereals and these proteins are of much better quality because they are very balanced in amino acids $[2,5]$;. Its consummation may contribute to fight against some illnesses like rickets, anemia, the dusky blindness and the scurvy, $[1,6,7]$. Because of its nutritional value, amaranth can be valorized through many products as tea, the cookies, yogurts and the infantile flours to fight malnutrition and to improve the health of the populations [8].

In Burkina Faso, the amaranth occupies an important place among the cultivated leafy-vegetable because it is more and more produced and consumed by the population.

However there is very few data on the extent of its culture, the different cultivated species and the agricultural ways of managements of its diversity. The present survey aims a better knowledge of the extent of the culture and the agricultural ways of management of the species of Amaranthus cultivated spp in Burkina in order to propose adequate methods of management, improvement and valorization. Thus, it is about collect the local knowledge about the management of the amaranth, and to identify the preferential characters for the populations. 


\section{Materials and Methods}

\subsection{Ethnobotanical Investigations and Collection of Cultivars}

The zones of cultivation of the amaranth are not well known considering it is in protoculture in Burkina. Thus, the services of the provincial directions of agriculture (PDA) have been solicited for the identification of the different villages where amaranth is cultivated. The data have been collected from the producers through individual and semi structured interviews. A form has permitted to collect some information from the producers about the origin, the number and the names of the local cultivated varieties, the cultural practices, the preferential morphological characters of the producers and consumers, the way of obtaining of seeds, the period of cultivation of the plant, the methods of conservation of seeds and the different uses. The collected accessions have been subtracted either in the fields, or in the dwellings, or in the gardens. Every accession is constituted of capsules or seeds.

\subsection{Statistical Analyses}

The software Excel 2013 has been used to entry the different data collected and the software XLSTAT 2016 has served to the estimation of the frequencies and the different evaluated parameters averages. The software Bow GI 9.2 permitted to draw the map of localization of the investigated and collection sites of the amaranth accessions.

\section{Results}

\subsection{State of the Culture of the Amaranth in Burkina}

All 45 provinces that Burkina counts have been identified as zone of culture of amaranth. However, 10 provinces have been prospected (image 1) and 170 producers distributed in five ethnic groups have been investigated. Ninety-nine (99) accessions have been collected among which $69.69 \%$ in the Sudano-sahelian zone, $20.2 \%$ in the Sahelian zone and $10.1 \%$ in the Sudanese zone. The majority of the investigated people $(67.97 \%)$ finds that the culture of amaranth is in net progression against $20.26 \%$ of the producers who estimate the steady production and $11.76 \%$ find it in regression. The picture 1 shows that the amaranth is mainly cultivated by the men $(64.45 \%$ against $35.55 \%$ for the women) and the Mossi ethnic groups (72.94\%), Gurunsi (12.35\%) and Bôbô $(11.76 \%)$. The culture of the amaranth is more practiced in the urban centers than in rural areas. Two systems of culture are practiced: the monoculture $(25.65 \%$ of the investigated) and the mixed culture $(74.35 \%$ of the investigated) in association with other vegetables such as jute (Corchorus olitorius), okra (Abelmoschus esculentus), cabbages (Brassica spp), sorrel (Hibiscus sabdarifa), lettuce (Lactuca sativa), spider plant (Cleome gynandra) and spinaches (Spinacia spp). The amaranth is cultivated as well as in rainy season and in dry season on the outskirts of dams or around wells. The exploited surfaces vary 0.062 ha and 0.7 ha with an average of 0.125 ha for the majority of the producers.

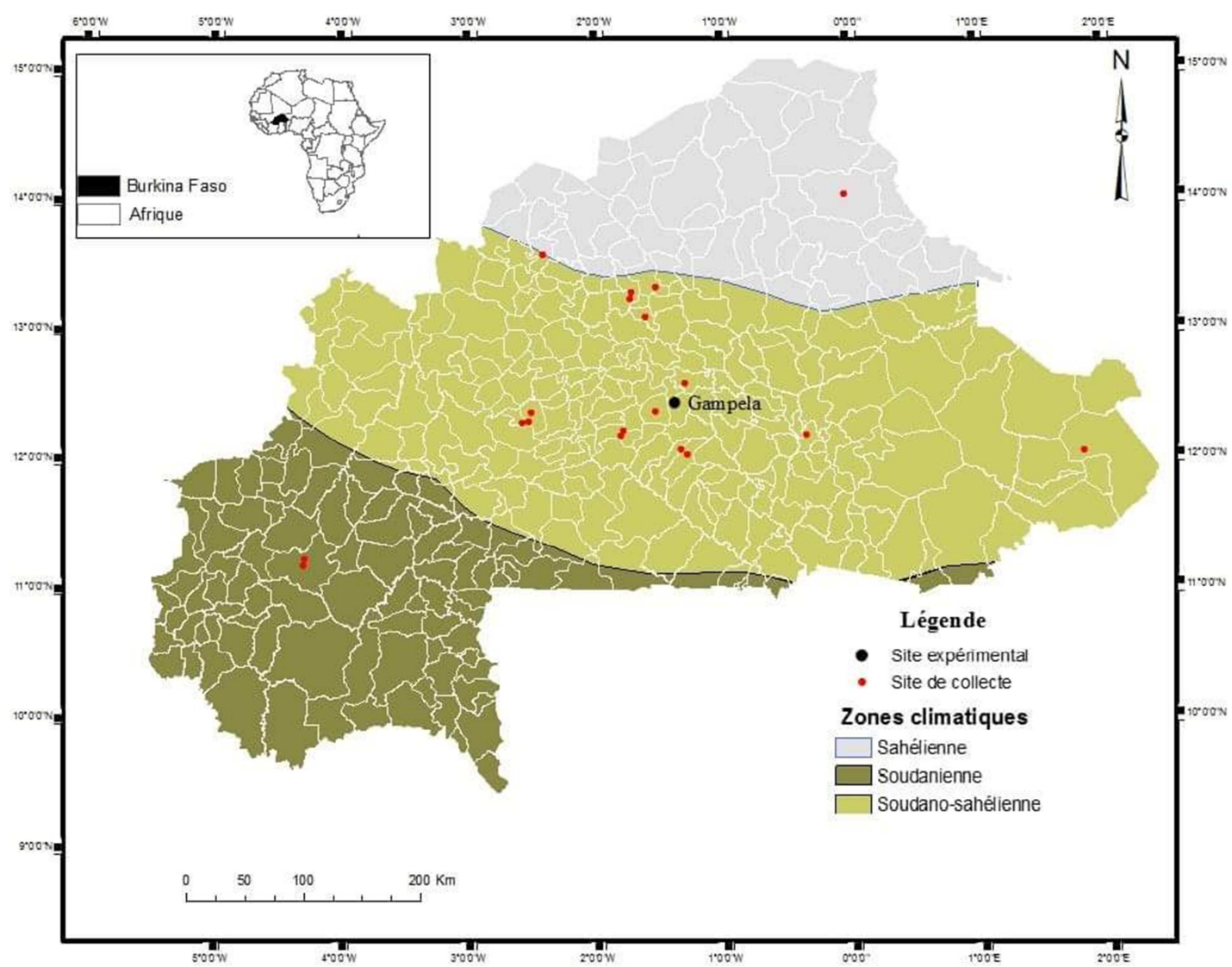

Figure 1. Investigated and collection sites of the amaranth accessions. 
Table 1. Distribution of the producers by climatical zone, sex and ethnical group.

\begin{tabular}{|c|c|c|c|c|}
\hline \multirow{2}{*}{ Climatical zones } & \multirow{2}{*}{ Ethnic group } & \multicolumn{2}{|l|}{ Sex } & \multirow{2}{*}{ Total } \\
\hline & & Men & Women & \\
\hline \multirow{3}{*}{ Sahelian } & Mossi & 21 & 00 & 21 \\
\hline & Gourmantché & 03 & 00 & 03 \\
\hline & Peul & 01 & 00 & 01 \\
\hline \multirow{3}{*}{ Sudano-sahelian } & Mossi & 50 & 54 & 104 \\
\hline & Gourmantché & 01 & 00 & 01 \\
\hline & Gurunsi & 16 & 05 & 21 \\
\hline Total & & 111 & 59 & 170 \\
\hline
\end{tabular}

\subsection{Etymological Diversity and Criteria of Denomination of the Amaranth}

Thirteen (13) vernacular names have been identifyed within the 5 ethnic groups (picture 2). The names generally vary according to the ethnical groups with more of diversity of names within the group of Mossi than the other groups (25 names of which 6 retained). However, the denomination "barambourou"is common to the ethnical groups.. It is the same way of the "Balamboule"denomination or "balboule" that are common to the Mossi, Gourmantches and fulany ethnic groups. The producers use the phenotypic and organoleptic characteristic to describe the «local varieties" of amaranth. Eight (8) «traditional varieties» have been identified based on the color of the stem and leaves, the size of the plant, the measurements and the shape of the leaves, the taste of the leaves in sauce and the wild or cultivated statute of the plant. Thus, according to the aspect of the leaves, two varieties called in local language mooré "Bouroumboure yanga" and "bouroumbouri raoogo" respectively meaning "female amaranth" and "male amaranth" have been identified. According to the taste of the edible parts, the denominations in Gurunsi "ejangio ouolo" and "ejangio ndè" that respectively mean amaranth "to sickening" odor and "amaranth to pungent" taste have been recorded. As for the color of the leaves and the stem, the denominations "bouloumboure miougou" in mooré and "ejangio nachion" in Gurunsi meaning red amaranth, "bouroumbouri sablga" in mooré and "ejangio nabiou" in Gurunsi that means "dark or black" green amaranth and "bouroumbouri peele or nassara", in moore and "ejangionapoan" in Gurunsi that means "clear" white or green amaranth have been noted. According to the statute the appellations "goejangio" or "ejangio too" meaning wild amaranth have been noted at the Gurunsi.

Table 2. Some names of the amaranth in local languages

\begin{tabular}{lll}
\hline $\mathbf{N}^{\circ}$ & Ethnical groups & Vernacular names \\
\hline 1 & Mossi & Broum-broum, Zilibe, Boulouboula, barambourou, balboule, lisambo \\
2 & Bôbô & Mouna, Mana, Barambourou \\
3 & Gurunsi & Ejangio, Juble \\
4 & Fulanese & Balamboule \\
5 & Gourmantché & Balmboule \\
\hline
\end{tabular}

\subsection{Cultural Practices and Characters of Interest of Amaranth in Burkina Faso}

Most of the producers $(84.40 \%)$ cultivate only "one variety" of amaranth. Only $15.59 \%$ of the producers cultivate many varieties together. The seeding is made either directly, by seed hole $(0.63 \%)$ or by blast $(22.78 \%)$, either indirectly, in nursery before the recording $(76.58 \%)$. The nurseries are made on small flower beds plowed to $10 \mathrm{~cm}$ depth, then fertilized with the organic manure and well watered. The seeds are generally mixed at the dry sand for the seedling by blast. A hoeing is done every week until the harvest of the leaves. Two types of harvest are practiced by the producers namely by extraction of the young plants while they are even tender (about 10-15 days after seedling) and by cut of the branches at intervals of two (2) weeks during the development of the plants. The eradication of devastating and the illnesses is made by using chemicals $(87.41 \%$ of the producers) or of bio pesticides $(10.47 \%)$. Chemical product commonly used are Decises 25EC, Savahalerwp, Cayman
Red P, Pasha 25EC, Biomec 18EC and Attakan 344SE that are ratified and the terrific Lamda, the Lamda master, IBISA 52EC that are non-ratified. Ash, the excerpts of neem (Azadirachtaindica) and the spiced solutions are used as bio pesticides. A minority of producers (2.09\%) scheme these two means of eradication at the same time.

The green morphotype is the most cultivated $(83.76 \%$ of the producers). The producers justify their preference by the availability of seeds, the significant vegetative development, the organoleptic qualities and the increase demand by the consumers of this morphotype. However, $80 \%$ of the producers of Bobo-Dioulasso produce the red morphotype in mixture with other morphotypes.

\subsection{Obtaining and Conservation Mode of Seeds}

Three ways of acquisition of seeds have been identified by the producers. That is selection practiced for $60.43 \%$ of the investigated, purchase for $16.54 \%$ and gift for $23.02 \%$ of them. Concerning selection, the most robust plants of the morphotypes are saved until complete maturity of the grains 
which are picked and preserved for the next season. The producers use varied methods for the conservation of seeds. Indeed, more than $40 \%$ preserve their seeds in cans, $23.41 \%$ in sachets, $12.65 \%$ and $3.16 \%$ respectively in boxes and in canaries. Others combine the methods such as the use of sachets and cans (14.55\%), bottles and cans (1.26\%), canaries and cans $(0.63 \%)$.

\subsection{Socioeconomic Importance of the Amaranth in Burkina Faso}

In Burkina Faso, the amaranth is mainly cultivated for the human consummation. Indeed, the leaves of the amaranth are used in the preparation of sauces with various local dishes such as the dough to basis by corn flour, mil or sorghum named locally "to", rice, the boiled yam, and couscous. The leaves of

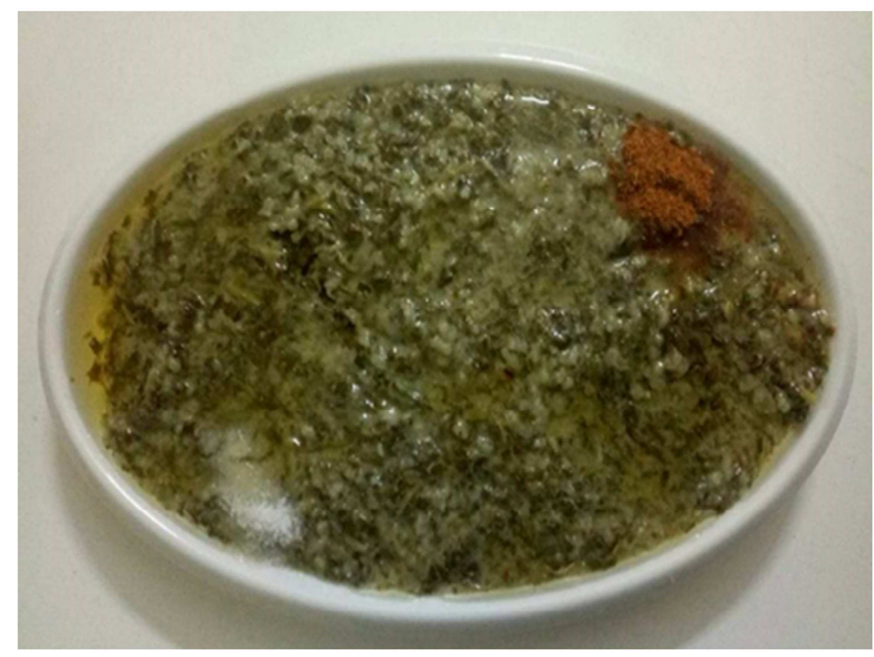

a. Dish of bag-benda the amaranth associated to leafy-vegetable others (spider plant sorrel) are also used in the preparation of a local dish named bag-benda in Moore language (picture 2a) and the "gnougou" in bwamu (wads of leaves mushes seasoned). The wild form of the amaranth serve as fodder for livestock. Besides its food role, the commercialization of the fresh leaves and seeds constitutes a source of income for the producers and the tradesmen. The leaves are sold by heap (picture $2 \mathrm{~b}$ ) in the markets for CFA 100 to $300(0.15 €$ to $0.46 €)$. As for seeds, they are sold in sachets or in cans of 0.5 to $1 \mathrm{~kg}$ for CFA 50 $(0.076 €)$ to CFA 3500 (5.34 €). The leaves of the amaranth are also used in traditional medicine in Burkina, to treat the stomach aches and of eyes aches. The consummation of the amaranth leaves boiled would permit to fight against hemorrhoids, hypertension, constipation, tiredness and malaria.

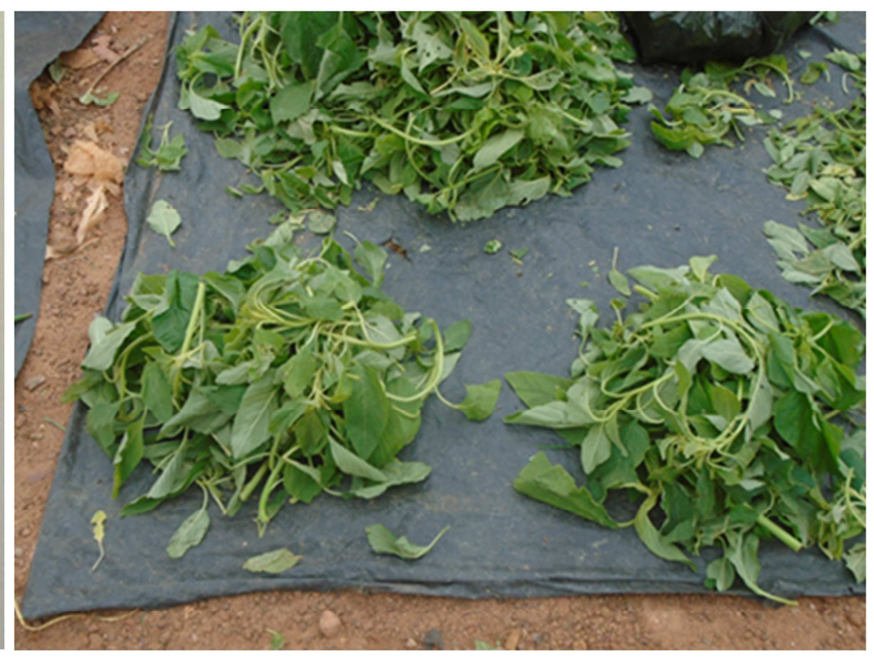

b. Heap of amaranth leaves

Figure 2. Some uses of the amaranth.

\section{Discussion}

The amaranth is as well known in all climatical zones of Burkina Faso as cultivated by several ethnical groups. Testify the diversity of morphotypes identified, the local names variability and its increasing demand as well in rural environment as in urban areas. Indeed, eight (8) morphotypes and 13 denominations based on the morphological, phenotypic and organoleptic characters have been noted by the producers. According to the [9], the local name is the basic element used by the producers in the genetic resources management and selection. Thus, the knowledge of farming nomenclature and the traditional system of classification of the varieties permits an understanding of the dynamics of their diversity. The growth of its production may be due to its lot use in various local dishes. That may contribute to the maintenance of some species. According to the [1], the maintenance of the traditional cooking represents a socioeconomic stake, but also strategic and ecological in the conservation of the genetic diversity. Otherwise, the weak production of the amaranth in the farming zones comparing to urban areas may be due to the fact that in urban environment the food habit has evolved a lot, tending to valorize local dishes whereas in rural areas, these plants are still stigmatized. Indeed, the leaves and the young branches are more and more integrating the food habit of the urban populations. The bag-benda (local dish from amaranth leaves) is more and more consumed in urban environment especially during wedding ceremonies, of naming ceremonies, funeral ceremonies. According to the [1], most of the time, tropical leaves-vegetables are produced in urban or out-of-town zone and less frequently in farming zone. They are considered nowadays as gardening plants and are more produced in dry season than in rainy season.

The denomination of the amaranth is function of the locality and the ethnic groups. However, the observed synonymy can be explained by the loans or a distortion of the original name due to the ethnic group subdivision in several dialects, especially in the group ethnic mossi, as it was the case of other vegetables like Corchorus oliotorus [10-11]. Indeed, according to the investigated people, the appellations may derive from the local name baram-bourou or borombrom that mean leaf of "baram" in dioula. Besides, the same nomenclature (borom-brom) is used by some ethnic groups in 
Ivory Coast Republic [12]. This survey reveals that the culture of the amaranth is in a net progression for the majority of the producers because of its increasing demand on the market. That is way it is produced in all seasons of the year in the urban and out-of-town zones in gardens, on the outskirts of the dams or around the wells. In rainy season, there is slump and fall of the prices because it pushes spontaneously at a time in the nature and the availability of all vegetables at a time. Like others vegetables in protoculture, such as Corchorus oliotorus [11] Cleome gynandra [13], the culture of the amaranth is practiced as well by the women as by the men in urban and out-of-town environment. In dry season its culture for the commercialization remains the appendage of men in urban environment. The women take care of the harvest and the sale of the leaves in the markets or yards of the urban zones. This may be due to the socio-cultural beliefs associated to the African socioeconomic organization. Indeed the earth belongs to the men who can bestow a portion or not to the women. According to the [14], the agricultural activity is mainly done by the women, but the agriculturists only have a relative limited access to the productive resources and the necessary services to the agricultural operators.

The green and red morphotypes are the most cultivated and consumed. According to the [1] also showed that the green and red amaranths are the most cultivated and used in Africa. According to the [15] the accessions of green type amaranth have features of preference of the women producers in Senegal. In Burkina, the gardeners orient the production of the amaranth toward the needs of the consumers like in Senegal. This observation has also been made by the [13] on the Cleome gynandra. This preference may lead to for loss of the diversity of the amaranth species.

In Burkina, the amaranth plant is still in protoculture. Then, the principal way of acquirement of seeds is less merchant. The different ethnic group producers practice the mass selection. This is also used for all vegetables in Burkina $[13,17,18]$. The conservation of the amaranth seeds in cans, bottles or plastic sachets have been reported by the same authors.

\section{Conclusion}

The amaranth is a species which is in protoculture in Burkina and cultivated by all the ethnic groups. Nowadays it is considered as a garden plant and is produced a lot in dry season than in rainy season. A great diversity of morphotypes has been described by the producers. But the green and red morphotypes are the most cultivated and consumed. The agro morphological and molecular characterizations of the accessions collected during this activity would permit to establish the real diversity of the amaranth cultivated in Burkina.

\section{Acknowledgements}

This research has been supported by International Foundation for Science (IFS), Sweden, through a scholarship given to Boureima SAWADOGO.

\section{References}

[1] Kahane R., Temple L., Brat P. and Of Good H., 2005. The tropical country leaves-vegetables: diversity, economic wealth and health value in a very fragile context. Angers symposia, 9 p.

[2] Grubben G. J. H., Denton O. A. (2004). Plant resources of tropical Africa 2. Vegetables. PROTA FOUNDATION, WAGENINGEN.

[3] Trucco F., Tranel FBI (2011) Amaranthus. In: Kole C (ed) Wild crop relative: genomic and breeding resources vegetables. Springer-Verlag, Berlin Heidelberg. (26): 11-21.

[4] Mburu M. W., Gikonyo N. K, Kenji G. M., Mwasaru A. M (2012). Nutritional and functional properties of has complementary food based on Kenyan amaranth grain (Amaranthus cruentus). African Journal of food agriculture nutrition and development 2 (2): 1-19.

[5] Adeyemi I. A., Komolafe A., Akindelei A. O., 2000. Properties of Steam Blanched Maize Flour ace has Constitute of Weaning Food. Department of Food Science Technology and, ObafemiAwolowo University, Island - Lfe, Standard Organization Nigeria of, 1988.

[6] Varalahsmi B., 2004. Characterization and preliminary assessment of amaranth (Amaranthus spp.) germplasm. PGR NEWSLETTER, FAO-BIOVERSITY. Exit No. 137, pp 55-57.

[7] Soro C. L., Ocho-Anin AtchibrI A. L., Armand K. K. K. and Christophe K., 2012. Assessment of the nutritional composition of the leaves-vegetables, J. Appl of. Biosci. 51: 3567-3573. ISSN 1997-5902.7P.

[8] Gbaguidi A., Sanoussi E. Y. F., Adjatin A., Agre P. S. A., Orobiyia., Dossou A. I., Dansi A., 2016. Strategic action plan heart the promotion of Amaranth and Bambara groundnut been worth chain Benin in. University of Abomey-Calavi of, 19p.

[9] Missihoun A. A., Agbangla C., Adoukonou-Sagbadja H., Ahanhanzo C. et Vodouhè R., 2012,. Traditional management and statute of the genetic resources of sorghum (Sorghum bicolor L. Moench) in the Northwest of Benin. Int. J. BIOL. Chem. Sci. 6 (3): 1003-1018.

[10] Dansi A., Adjatin A., Adoukonou-Sagbadja H., Adomou A., Falade V., Yedomonhan H., Akpagana K., De Foucault B., 2008,. Traditional leafy vegetables Benin in: Folk nomenclature, species under threat and domestication In: Biodiversité des legumes-feuillestraditionnels consommés au Bénin. Bibliotèque nationale, Bénin $p 173$.

[11] Kiebre M., Kiebre Z., Traore RE, Bationo/Kando p., Sawadogo n., Sawadogo M., 2017. Ethnobotanical and agromorphological characterizations of corchorus olitorius L. accessions in Burkina Faso. Journal of Experimental Biology and Agricultural Sciences, 12p.

[12] Fondio L., Mahyao A., Agbo A. E., Gbesso M. F., 2012. Well cultivate the amaranth, the celosia, the edible corète and the nightshade in Coast of Ivory. National Center of Agronomic Research, $4 \mathrm{p}$.

[13] Kiebré Z., 2016. Genetic diversity of the white Caya (Cleome L. gynandra) of Burkina. Thesis doct. Univ. Ouaga, 126 p. 
[14] FAO, 2011. The world food and agriculture situation: the role of women in agriculture, $174 \mathrm{p}$.

[15] Diouf M., Mbengue N. B. and Kante A., 2007. Characterization of the accessions of 4 species of traditional leaves-vegetables (Hibiscus sabdariffa L. Vignaunguiculata (L.) WALP, Amaranthus L. spp and Moringa LAM oleifera) in the Sénégal. African Journal of food agriculture and nutrition. 16pages.

[16] Kiebre M., Bationo/Kando P., Kiebré Z., Sawadogo M., Sawadogo N., Sawadogo B., Nanéma R. K., and Traoré R. E., 2016. Agro morphologic assessment of accessions of edible corète (Corchorus olitorius. L) of Burkina. International Journal of Innovation and Applied Studies vol. 14 No. 1, pp. 198-209.

[17] Bationo-Kando P., Sawadogo B., Nanéma K. R., Kiébré Z., Sawadogo N., Kiébré M., Traoré R. E., Sawadogo M., Zongo J. D., 2015. Characterization of Solanum ethiopicum (Kumba group) Burkina in. International Journal of Sciences and Nature Vol. 6 (2): 169-176 ISSNS 2278 - 9103.

[18] Ouédraogo M. H., 2016. Survey of the genetic diversity of gumbos [Abelmoschus esculentus (L.) $\mathrm{MOENCH}$ ] cultivated in Burkina, Thesis doc. Univ. Ouaga, 158p. 